\title{
Characteristics of Quality of Work Life on Employees at Consultant Company in Indonesia
}

\author{
Mahendra FAKHRI ${ }^{1}$, Ida NURNIDA ${ }^{2}$, Alex WINARNO ${ }^{3}$, Benny KURNIA ${ }^{4}$, Deki SURYANA ${ }^{5}$
}

Received: August 01, 2020 Revised: October 05, 2020 Accepted: October 15, 2020

\begin{abstract}
The study aims to investigates and explore the quality of work life (QWL) and also to find out which QWL factors are considered as primary factors among employees of PT. Duta Transformasi Insani, a consulting service management in Indonesia. The factors of QWL in this study consist of nine components, which are: work environment, organizational culture and climate, relation and cooperation, training and development, reward and compensation, facilities, job satisfaction and job security, work autonomy, and resource adequacy. This study conducted a survey of every employee who works for PT. Duta Insani, which consists of various sample characteristics, such as gender, education level, and length of employment. The descriptive analysis also analyzes how the QWL condition in this company. The method in this research using quantitative descriptive and factor analysis, together with validity and reliability tests, to fulfill the study objectives. The results showed that most dimensions of employees' QWL are within a valid category, with an 80 percent average of this variable. Furthermore, the results also indicate there are two major factors constituting the quality of work life of the employees of PT. Duta Transformasi, which are supportive organizational culture, accounting for 47.75 percent, and organizational facilities, accounting for 13.03 percent.
\end{abstract}

Keywords: Quality of Work Life, Organization, Human Capital

JEL Classification Code: J20, J24, J28

\section{Introduction}

Human resources are the primary factor for an organization to achieve expected performance (Northouse, 2019). Certain qualifications of employees within an organization affect how they use the resources. An ineffective and operationally

${ }^{1}$ First Author and Corresponding Author. School of Communication and Business, Telkom University, Indonesia [Postal Address: Jl. Telekomunikasi No. 1, Terusan Buah Batu Kec. Bojongsoang, Kabupaten Bandung, Jawa Barat, 40257, Indonesia]

Email: mahendrafakhri@telkomuniversity.ac.id

${ }^{2}$ School of Communication and Business, Telkom University, Indonesia

${ }^{3}$ School of Communication and Business, Telkom University, Indonesia

${ }^{4}$ School of Communication and Business, Telkom University, Indonesia

${ }^{5}$ School of Communication and Business, Telkom University, Indonesia

(c) Copyright: The Author(s)

This is an Open Access article distributed under the terms of the Creative Commons Attribution Non-Commercial License (https://creativecommons.org/licenses/by-nc/4.0/) which permits unrestricted non-commercial use, distribution, and reproduction in any medium, provided the original work is properly cited. inefficiency procedure will result in unexpected costs against organization. Therefore, keeping employees is the first step to achieve organizational goals optimally (Robbins \& Judge, 2017).

PT. Duta Transformasi Insani is a company engaged in management consulting services, training, courses, event organizers, and business laboratories in various forms that can be adjusted to client's needs. In order to compete and survive PT. Duta Transformation Insani has to upgrade and maintain quality, performance, and work environment for their employees. Innovation and effective style of leadership also needed as a strategy to maintain consumer satisfaction toward their company as well as building employee's motivation and performance (Pradana, et al., 2020; Saragih, et al., 2018). Without a defined strategy of how to respond and an appreciation of the characteristics of the consumer, firms will remain vulnerable to any competitors (Becker \& Lee, 2019).

Hermawati (2017) states that one of the concepts to develop a better work environment for employees is Quality of Work Life (QWL). QWL is an effort from employees to enhance their working conditions, their duties, work safety, 
security, benefits, and compensation (Jabeen et al., 2018). This concept emphasizes the importance of respect for humans in their work environment because the main focus of QWL is not to make work better, but emphasizes how work can make employees' lives better. Therefore, an organization must provide resources needed by employees to apply quality of work life inside the organization (Dechawatanapaisal, 2017).

A better quality of work life can be exemplified by matching job functions with employee requirements. Employees should be well aware of their own rights and benefits (Nguyen \& Pham, 2020). The QWL is a program designed to increase employee satisfaction toward their work environment along with their productivity (Aryeetey \& Sanda, 2012). Particular organization characteristic such as policies, leadership, operational procedure, and any other supportive characteristic displayed by an organization can produce a different output for every member of the organization (Hoa et al., 2020). QWL holds an important role to develop employee perception toward the organization as well as how employees decide whether they will stay in or leave the organization (Kara et al., 2018). Employee commitment to the organization can improve its performance, due to a sense of belonging from the employees themselves (Winarno \& Hermana, 2019). It is essential to pay attention to employee QWL because enhancing employee QWL will affect how they are involved in work and how the organization uses of their workforce skills (Dargahi \& Seragi, 2007)

When employees feel satisfied with the organization, it will affect their commitment while carrying out organization duties (Fakhri et al., 2019). QWL also has a significant impact on society. Employees who feel happy within the organization will carry over their feelings around and into their family or communities (Paais et al., 2020). Therefore, QWL is necessary to deal with the demanding way of life and become a way to fulfill organization duties and balancing both work life and family life (Bagtasos, 2011).

The quality of work life concept has also fascinated researchers for many years and has been an area of interest to psychologists and sociologist, but now it has gained momentum among scholars and academicians as well (Sirgy et al., 2001; Back et al., 2011). It is worthwhile to mention that, if the employees of any concern are satisfied in relation to their work life quality, they can certainly produce good results (Brunges \& Foley-Brinza, 2014; Yuh \& Choi, 2017).

According to Swamy et al. (2015), nine factors describe QWL are: work environment, organizational culture and climate, cooperation and relation, training and development, facility, work satisfaction and safety, work independence, and resource adequacy. This research aims to identify how PT. Duta Transformasi Insani has implemented the concept of quality of work life or QWL. In order to assess how QWL is perceived in the present situation, researchers conducted a preliminary study by distributing questionnaires to several employees at PT. Duta Transformasi Insani regarding the Quality of Work Life component based on Swamy's factors. The results of the preliminary study show that all factors have been felt by the employees of PT Duta Transformasi Insani. Organizational culture and climate obtain the highest value of all factors. This preliminary study provided a preliminary perspective on quality of work life perceived by the employee.

\section{Literature Review}

\subsection{Quality of Work Life}

QWL can be defined as the favorable conditions and environments of a workplace that support and promote employee satisfaction by providing workers with rewards, job security, and growth opportunities (May et al., 1999). Job security, better reward systems, higher pay, opportunity for growth, participative groups, and increased organizational productivity are the main issues discussed in the extant QWL literature. Under the service profit chain model, QWL has also been interpreted as 'internal service quality' to the quality of work environment that contributes to employee satisfaction (Heskett et al., 1994).

QWL is said to differ from job satisfaction (Quinn \& Shephard, 1974; Davis \& Cherns, 1975; Hackman \& Suttle, 1977; Kabanoff, 1980; Near et al., 1980), but QWL is thought to lead to job satisfaction. QWL refers to the impact of the workplace on satisfaction in work life (job satisfaction), satisfaction in non-work life domains, and satisfaction with overall life (Sirgy et al., 2001). Some researchers (Danna \& Griffin, 1999) see QWL as a hierarchy of concepts that include non-work domains such as life satisfaction (at the top of the hierarchy), job satisfaction (at the middle of the hierarchy) and more work-specific facets of job satisfaction including such things as pay, co-workers, and supervisor (lower in the hierarchy).

Although QWL originated over three decades ago, the interest in the construct has not waned. QWL also has a connection with a person's intention to have a better work situation, wherein an intention can be defined as a personal motivation to withstand a particular situation, whether its beneficial or not (Pradana et al., 2020). During the 1990s, scholars and practitioners revived an interest in the study of QWL, and this concept has become of renewed concern and increased importance to the organization and its human resources both in terms of employee job satisfaction and ultimate performance of the organization. People began to know more about quality of work life when the United Auto Workers and General Motors introduced a QWL program for work reform (Beer et al., 1985; May, 1999). 
Mahendra FAKHRI, Ida NURNIDA, Alex WINARNO, Benny KURNIA, Deki SURYANA I

Journal of Asian Finance, Economics and Business Vol 7 No 11 (2020) 1105-1111

The QWL construct used in this article is based on a modified version of the notion developed by Swamy (2015), which use nine factors such as: work environment, organizational culture and climate, relation and cooperation, training and development, reward and compensation, facilities, job satisfaction and job security, work autonomy, and resource adequacy. The model for this research, based on Swamy's finding about QWL, is shown below:

\section{Research Methods}

The research method is a scientific way to obtain data with specific purposes and uses. The type of research used in this research is quantitative descriptive with factor analysis. Descriptive research is conducted to determine the value of each variable, whether one or more variables are independent without entertaining relationships or comparisons with other variables. These variables can describe systematically and accurately a population or a particular area of analysis of research efforts, but are not used to reach broader conclusions. Quantitative method is defined as a research method based on the philosophy of positivism, used to research on certain populations or samples, data collection using research instruments, quantitative or statistical data analysis, with the aim of testing predetermined hypotheses.

Factor analysis can be used to reduce data; factors (also called dimensions or components) can be found that can represent the original variables. The function of factor analysis is to identify fundamental dimensions that can explain the correlation of a series of variables (Gilang et al., 2019). Based on previous studies, the researchers are using both descriptive and factor analysis in order to conduct this research.

\section{Results and Discussion}

\subsection{Validity and Reliability Test}

The average percentage score for the facilities factor has a value of $82.00 \%$, which is a valid category. Percent average score for job satisfaction and security factors has a value of $78.67 \%$, which is a valid category. The average percentage score for the work autonomous factor has a value of $81.11 \%$, which is a valid category. The average score percentage for the resource adequacy factor has a value of $79.00 \%$, which is a valid category.

\subsection{Descriptive Analysis}

The average percentage score for work environment factors has a value of $82.44 \%$, and this score within a valid category. The average score percentage for organizational culture and climate factors has a value of $81.33 \%$, and this score is within a valid category. The average percentage score for the relationship and cooperation factor has a value of $80.89 \%$, and this score is within a valid category. The average score percentage for the training and development factor has a value of $82.00 \%$, and this score is within a valid category. The average percentage score for the reward and compensation variables has a value of $83.33 \%$, and this score is within a valid category.

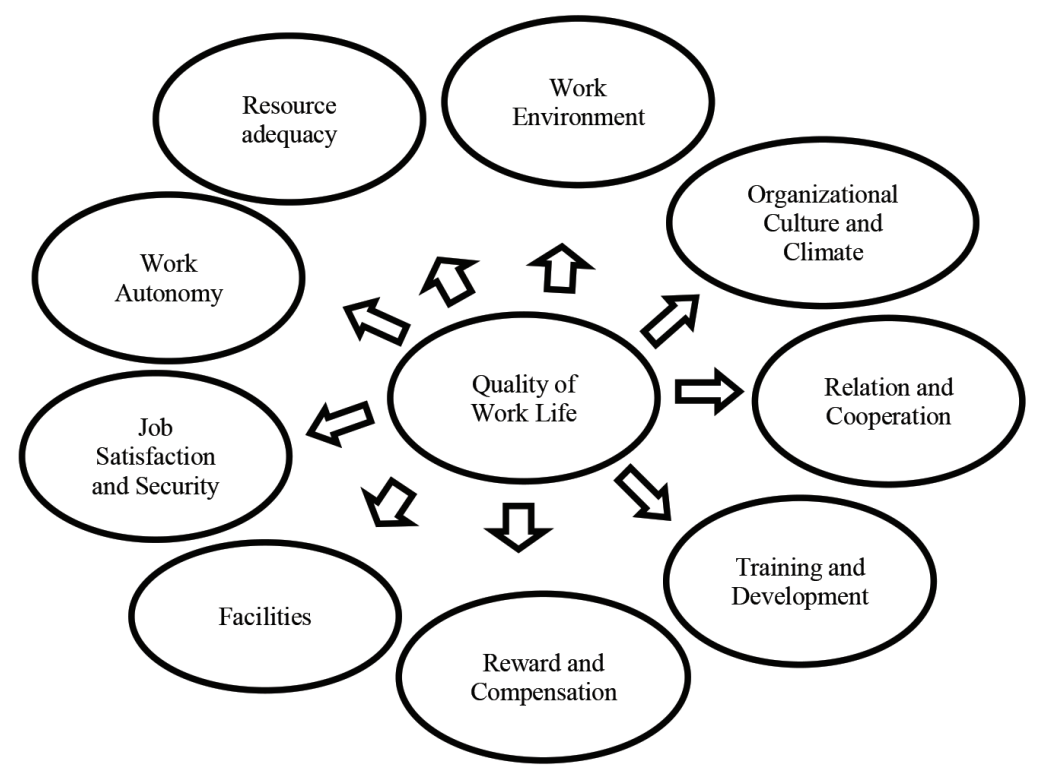

Figure 1: Research Model 
Table 1: Validity Test

\begin{tabular}{|c|c|c|c|c|}
\hline Dimensions & Item & Factor Loading & Factor Loading & Label \\
\hline \multirow[t]{3}{*}{ Work environment } & P1 & 0.300 & 0.737 & valid \\
\hline & $\mathrm{P} 2$ & 0.300 & 0.550 & valid \\
\hline & P3 & 0.300 & 0.675 & valid \\
\hline \multirow{4}{*}{$\begin{array}{l}\text { Organizational culture and } \\
\text { climate }\end{array}$} & $\mathrm{P} 4$ & 0.300 & 0.507 & valid \\
\hline & P5 & 0.300 & 0.805 & valid \\
\hline & P6 & 0.300 & 0.651 & valid \\
\hline & $\mathrm{P} 7$ & 0.300 & 0.581 & valid \\
\hline \multirow[t]{3}{*}{ Relation and cooperation } & P8 & 0.300 & 0.721 & valid \\
\hline & P9 & 0.300 & 0.642 & valid \\
\hline & P10 & 0.300 & 0.609 & valid \\
\hline \multirow[t]{2}{*}{ Training and development } & P11 & 0.300 & 0.695 & valid \\
\hline & P12 & 0.300 & 0.643 & valid \\
\hline \multirow[t]{3}{*}{ Reward and compensation } & P13 & 0.300 & 0.783 & valid \\
\hline & P14 & 0.300 & 0.514 & valid \\
\hline & P15 & 0.300 & 0.332 & valid \\
\hline Facilities & P16 & 0.300 & 0.550 & valid \\
\hline \multirow[t]{2}{*}{ Job satisfaction and job security } & P17 & 0.300 & 0.735 & valid \\
\hline & P18 & 0.300 & 0.668 & valid \\
\hline \multirow[t]{3}{*}{ Work autonomy } & P19 & 0.300 & 0.521 & valid \\
\hline & P20 & 0.300 & 0.517 & valid \\
\hline & P21 & 0.300 & 0.496 & valid \\
\hline \multirow[t]{2}{*}{ Resource adequacy } & P22 & 0.300 & 0.450 & valid \\
\hline & P23 & 0.300 & 0.541 & valid \\
\hline
\end{tabular}

Table 2: Reliability Test

\begin{tabular}{|l|c|c|}
\hline Cronbach's Alpha & N of Items & Result \\
\hline 0.878 & 9 & Reliable \\
\hline
\end{tabular}

Table 3: KMO and Bartlett's Test

\section{KMO and Bartlett's Test}

Kaiser-Meyer-Olkin Measure of Sampling Adequacy.

Bartlett's Test of Sphericity

\begin{tabular}{|c|c|}
\hline Approx. Chi-Square & .827 \\
\hline $\mathrm{df}$ & 130.338 \\
\hline Sig. & 36 \\
\hline
\end{tabular}

\subsection{Factor Analysis}

The result of KMO sampling adequacy is 0.827 , which is bigger than 0.5 as a minimum point to passed sampling adequacy. The result of MSA value for all variables is bigger than 0.5. It is passed as a minimum requirement in MSA Value. All nine factors can be analyzed further to be included in the factor analysis process since its extraction value is qualified. There are two factors with eigenvalues above the minimum requirement value, which is 1.00 . 
Table 4: MSA Value

\begin{tabular}{|l|c|l|c|}
\hline & No. & \multicolumn{1}{|c|}{ Indicator } & MSA Value \\
\hline Anti-image Covariance & 1 & Work environment & .830 \\
\cline { 2 - 4 } & 2 & Organizational culture and climate & $.778^{\mathrm{a}}$ \\
\cline { 2 - 4 } & 3 & Relation and cooperation & $.807^{\mathrm{a}}$ \\
\cline { 2 - 4 } & 4 & Training and development & $.925^{\mathrm{a}}$ \\
\cline { 2 - 4 } & 5 & Reward and compensation & $.804^{\mathrm{a}}$ \\
\cline { 2 - 4 } & 6 & Facilities & $.778^{\mathrm{a}}$ \\
\cline { 2 - 4 } & 7 & Job satisfaction and job security & $.909^{\mathrm{a}}$ \\
\cline { 2 - 4 } & 8 & Work autonomy & $.860^{\mathrm{a}}$ \\
\cline { 2 - 4 } & 9 & Resource adequacy & $.736^{\mathrm{a}}$ \\
\hline
\end{tabular}

Table 5: Communalities

\begin{tabular}{|l|c|c|}
\hline Communalities & Initial & Extraction \\
\hline Work environment & 1.000 & .709 \\
\hline Organizational culture and climate & 1.000 & .830 \\
\hline Relation and cooperation & 1.000 & .770 \\
\hline Training and development & 1.000 & .670 \\
\hline Reward and compensation & 1.000 & .674 \\
\hline Facilities & 1.000 & .627 \\
\hline Job satisfaction and job security & 1.000 & .625 \\
\hline Work autonomy & 1.000 & .638 \\
\hline Resource adequacy & 1.000 & .536 \\
\hline Extraction Method: Principal Component Analysis. & & \\
\hline
\end{tabular}

Table 6: Total Variance Explained

\begin{tabular}{|c|c|c|c|c|c|c|c|c|c|}
\hline \multicolumn{10}{|c|}{ Total Variance Explained } \\
\hline \multirow[t]{2}{*}{ Component } & \multicolumn{3}{|c|}{ Initial Eigenvalues } & \multicolumn{3}{|c|}{$\begin{array}{c}\text { Extraction Sums of Squared } \\
\text { Loadings }\end{array}$} & \multicolumn{3}{|c|}{$\begin{array}{c}\text { Rotation Sums of Squared } \\
\text { Loadings }\end{array}$} \\
\hline & Total & $\begin{array}{c}\% \text { of } \\
\text { Variance }\end{array}$ & $\begin{array}{c}\text { Cumulative } \\
\%\end{array}$ & Total & $\begin{array}{c}\% \text { of } \\
\text { Variance }\end{array}$ & $\begin{array}{c}\text { Cumulative } \\
\%\end{array}$ & Total & $\begin{array}{c}\% \text { of } \\
\text { Variance }\end{array}$ & $\begin{array}{c}\text { Cumulative } \\
\%\end{array}$ \\
\hline 1 & 4.775 & 53.059 & 53.059 & 4.775 & 53.059 & 53.059 & 3.442 & 38.241 & 38.241 \\
\hline 2 & 1.303 & 14.478 & 67.537 & 1.303 & 14.478 & 67.537 & 2.637 & 29.297 & 67.537 \\
\hline 3 & .819 & 9.100 & 76.637 & & & & & & \\
\hline 4 & .517 & 5.748 & 82.385 & & & & & & \\
\hline 5 & .480 & 5.329 & 87.714 & & & & & & \\
\hline 6 & .419 & 4.660 & 92.374 & & & & & & \\
\hline 7 & .275 & 3.060 & 95.434 & & & & & & \\
\hline 8 & .266 & 2.953 & 98.387 & & & & & & \\
\hline 9 & .145 & 1.613 & 100.000 & & & & & & \\
\hline
\end{tabular}


Table 7: Rotated Component Matrix

\begin{tabular}{|l|c|c|}
\hline \multirow{2}{*}{ Rotated Component Matrix ${ }^{\mathbf{a}}$} & \multicolumn{2}{|c|}{ Component } \\
\cline { 2 - 3 } & $\mathbf{1}$ & $\mathbf{2}$ \\
\hline Work environment & .829 & .147 \\
\hline Organizational culture and climate & .897 & .162 \\
\hline Relation and cooperation & .841 & .248 \\
\hline Training and development & .676 & .462 \\
\hline Reward and compensation & .400 & .717 \\
\hline Facilities & .142 & .779 \\
\hline Job satisfaction and job security & .730 & .303 \\
\hline Work autonomy & .183 & .778 \\
\hline Resource adequacy & .199 & .704 \\
\hline Extraction Method: Principal Component Analysis. & \\
\hline Rotation Method: Varimax with Kaiser Normalization. & & \\
\hline a. Rotation converged in 3 iterations. & & \\
\hline
\end{tabular}

After further calculation, two factors emerge as new factors in QWL. The first factor is named supportive organizational culture (work environment, organizational culture and climate, relation and cooperation, training and development, job satisfaction and job security) and the second factor is named organization facilities (reward and compensation, facilities, work autonomy).

\section{Conclusion}

This research shows that Quality of Work Life (QWL) among employees is a relevant category, and there are two factors to support QWL, namely, supportive organizational culture and organizational facilities. These factors indicate they are having a positive effect on employees' QWL. Positive attitudes from employees will suggest to improve their behavior, thus aligning with organizational culture and reduce deviant workplace behavior (Augustrianto et al., 2019). Based on this, it is clear that the primary objective of QWL, successfully implemented by organization, is to improve working conditions and greater organizational effectiveness. Positive results of QWL have been supported by a number of studies, including reduced absenteeism, lower turnover, and improved job satisfaction (Havlovic, 1991; Cohen et al., 1997; King \& Ehrhard, 1997). Several studies also indicate when employees experience a better QWL, they have a chance to improve their quality of life. Thus, if job redesign or job enrichment contribute to improving the sense of quality of work life of employees, it may also result in a sense of higher quality of life for those people (Elizur \& Shye, 1990).

\section{References}

Aryeetey, M., \& Sanda, A. (2012). Understanding employees' perspective of quality of work life indicators in Ghanaian organizations. International Journal of Contemporary Business Studies, 3(3), 17-30.

Augustrianto, A., Silvianita, A., \& Ferari, E. (2019). Hofstede's organization culture on deviant workplace behavior (Case study on workers at plaza Toyota Bandung). Journal of Advanced Research in Dynamical and Control Systems, 11(3), 720-725.

Back, K. J., Lee, C. K., \& Abbott, J. (2011). Internal relationship marketing: Korean casino employees' job satisfaction and organizational commitment. Cornell Hospitality Quarterly, 52(2), 111-124.

Bagtasos, M. R. (2011). Quality of Work Life: A Review of Literature. DLSU Business \& Economics Review, 20(2), 1-8.

Becker, K., \& Lee, J. W. (2019). Organizational usage of social media for corporate reputation management. Journal of Asian Finance, Economics and Business, 6(1), 231-240. http://doi. org/10.13106/jafeb.2019.vol6.no1.231

Beer, M., Spector, B., Lawrence, P. R., Mills, D. Q., \& Walton, R. E. (1985). Human Resource Management: A General Manager's Perspective. New York, NY: The Free Press.

Brunges, M., \& Foley-Brinza, C. (2014). Projects for increasing job satisfaction and creating a healthy work environment. $A O R N$ Journal, 100(6), 670-681.

Cohen, S. G., Chang, L., \& Ledford, G. E. (1997). A hierarchical construct of self-management leadership and its relationship to quality of work life and perceived work group effectiveness. Personnel Psychology, 50(2), 275-308. 
Mahendra FAKHRI, Ida NURNIDA, Alex WINARNO, Benny KURNIA, Deki SURYANA /

Journal of Asian Finance, Economics and Business Vol 7 No 11 (2020) 1105-1111

Danna, K., \& Griffin, R. (1999). Health and well-being in the workplace: a review and synthesis of the literature. Journal of Management, 25(3), 357-384.

Dargahi, H., \& Seragi, J. N. (2007). An approach model for employees' improving quality of work life (IQWL). Iranian J. Publ. Health, 36(4), 81-86.

Davis, L., \& Cherns, A. (1975). The Quality of Working Life. New York, NY: Free Press.

Dechawatanapaisal, D. (2017). The mediating role of organizational embeddedness on the relationship between quality of work life and turnover. International Journal of Manpower, 38(5), 696711.

Elizur, D., \& Shye, S. (1990). Quality of Work Life and its Relation to Quality of Life. Applied Psychology, 39(3), 275-291.

Fakhri, M., Pradana, M., Syarifuddin, S., Hafid, H., \& Mustika, N. P. (2019). Analyzing work satisfaction of employees at production department: Case study of indonesian state military equipment manufacturer. International Journal of Advanced Science and Technology, 28(8s), 163-175.

Gilang, A., Syarifuddin, S., Pradana, M., Fakhri, M., \& Maisarah, N. (2019). Factors Analysis of Basic Human Values at Indonesian Insurance Company. International Journal of Advanced Science and Technology, 28(8s), 755-763.

Hackman, J., \& Suttle, J. (1977). Improving Life at Work. Glenview, IL: Scott- Foresman.

Havlovic, S. J. (1991). Quality of work life and human resource outcomes. Industrial Relations, 30(3), 469-479.

Hermawati, A., \& Mas, N. (2017). Mediation effect of quality of worklife, job involvement, and organizational citizenship behavior in relationship between transglobal leadership to employee performance. International Journal of Law and Management, 59(6), 1143-1158.

Heskett, J., Jones, T. O., Loveman, G., Sasser, W., \& Schlesinger, L. A. (1994). Putting the service-profit chain to work. Harvard Business Review, March-April, 164-174.

Hoa, N. D., Ngan, P. T., Quang, N. M., Thanh, V. B., \& Quyen, H. V. (2020). An Empirical Study of Perceived Organizational Support and Affective Commitment in the Logistics Industry. Journal of Asian Finance, Economics and Business, 7(8), 589-598. https://doi.org/10.13106/jafeb.2020.vol7.no8.589

Jabeen, F., Friesen, H. L., \& Ghoudi, K. (2018). Quality of work life of Emirati women and its influence on job satisfaction and turnover intention. Journal of Organizational Change Management, 31(2), 352-370.

Kabanoff, B. (1980). Work and non-work: a review of models, methods and findings. Psychological Bulletin, 88, 60-77.

Kara, D., Kim, H., Lee, G., \& Uysal, M. (2018). The moderating effects of gender and income between leadership and quality of work life (QWL). International Journal of Contemporary Hospitality Management, 30(3), 1419-1435.

King, A. S., \& Ehrhard, B. J. (1997). Diagnosing organizational commitment: An employee cohesion exercise. International Journal of Management, 14(3), 317-325.
May, B., Lau, R., \& Johnson, S. K. (1999). A longitudinal study of quality of work life and business performance. South Dakota Business Review, 58, 1-7.

Near, J., Rice, R., \& Hunt, R. (1980). The relationship between work and nonwork domains: a review of empirical research. Academy of Management Review, 5, 415-429.

Nguyen, L. G., \& Pham, H. T. (2020). Factors Affecting Employee Engagement at Not-For-Profit Organizations: A Case in Vietnam. Journal of Asian Finance, Economics and Business, 7(8), 495-507. https://doi.org/10.13106/jafeb.2020.vol7.no8. 495

Northouse, P. G. (2019). Leadership Theory and Practice 8th Edition. Thousand Oaks, CA: Sage Publications.

Paais, M., Pattiruhu, J. R., Sopiah, S., Kurniawan, D. T., Nora, E., \& Narmaditya, B. S. (2020). Effect of Motivation, Leadership, and Organizational Culture on Satisfaction and Employee Performance. Journal of Asian Finance, Economics and Business, 7(8), 577-588. https://doi.org/10.13106/jafeb.2020. vol7.no8.577

Pradana, M., Pérez-Luño, A., \& Fuentes-Blasco, M. (2020). Innovation as the key to gain performance from absorptive capacity and human capital. Technology Analysis \& Strategic Management, 32(7), 822-834.

Pradana, M., Wardhana, A., Wijayangka, C., Kartawinata, B. R., \& Wahyuddin, S. (2020). Indonesian university students' entrepreneurial intention: A conceptual study. Journal of Critical Reviews, 7(7), 571-573.

Quinn, R., \& Shephard, I. (1974). The 1972-1973 Quality of Employment Survey. Ann Arbor: MI: Institute for Social Research, University of Michigan.

Robbins, S. P., \& Judge, T. A. (2017). Organizational Behavior (1 $7^{\text {th }}$ ed.). Harlow, UK: Pearson Education.

Saragih, R., Fakhri, M., Pradana, M., Gilang, A., \& Vidjashesa, G. A. (2018). Ethical leadership's effect on employee discipline: Case of an Indonesian telecommunication company. In: International Conference on Industrial Engineering and Operations Management (pp. 1630-1638). Johannesburg, South Africa: IEOM Society International.

Sirgy, M. J., Efraty, D., Siegel, P., \& Lee, D. J. (2001). Anew measure of quality of work life (QWL) based on need satisfaction and spillover theories. Social Indicators Research, 55(3), 241-302.

Swamy, D. R., Nanjundeswaraswamy, T. S., \& Rashmi, S. (2015). Quality of work life: scale development and validation. International Journal of Caring Sciences, 8(2), 281.

Winarno, A., \& Hermana, D. (2019). Commitment, work engagement, and research performance of lecturers in Indonesia private universities. Malaysian Online Journal of Educational Management, 7(4), 45-63.

Yuh, J., \& Choi, S. (2017). Sources of social support, job satisfaction, and quality of life among childcare teachers. The Social Science Journal, 54(4), 450-457. 